\title{
DIVERSE CHLAMYDIA-LIKE AGENTS ASSOCIATED WITH EPITHELIOCYSTIS INFECTION IN TWO CYPRINID FISH SPECIES, THE COMMON CARP (CYPRINUS CARPIO L.) AND THE GIBEL CARP (CARASSIUS AURATUS GIBELIO L.)
}

\author{
Boglárka SELLYEI*, Kálmán MOLNÁR and Csaba SzÉKELY \\ Institute for Veterinary Medical Research, Centre for Agricultural Research, \\ Hungarian Academy of Sciences, Hungária krt. 21, H-1143 Budapest, Hungary
}

(Received 1 August 2016; accepted 2 November 2016)

\begin{abstract}
During a general annual fish health survey in natural waters and ponds, epitheliocystis infections were recorded in fingerlings of two cyprinid fish species, the cultured common carp and the wild gibel carp. Benign and heavy infections were equally observed without mortality. In addition to the general health inspection of fish, histopathological examinations of infected gills and molecular biological investigations of separated epitheliocysts were performed. Epitheliocysts were formed both in the interlamellar epithelial cells and in the lamella-free multilayered epithelium of the gill filaments. At the early stage of infection darkstaining inclusion bodies densely stuffed with some pathogenic agents were located at the centre of the cell, while in a progressive stage of the process inclusion bodies within the host cells were disseminated in the cytoplasm and stained pale. Molecular studies demonstrated three different agents related to Neochlamydia, Protochlamydia and Piscichlamydia based on sequence analysis of short regions of the 16S rRNA gene. Among them, Piscichlamydia is a primary fish pathogen, while Neochlamydia and Protochlamydia mostly infect free-living amoebae but have adapted thoroughly to fish.
\end{abstract}

Key words: Epitheliocystis, Chlamydia-like, common carp, gibel carp

Epitheliocystis is a disease characterised by cytoplasmic bacterial inclusions (cysts) in epithelial cells of the gills and rarely of the skin in fish. This infection has been reported from over 90 fish species all over the world (Nowak and LaPatra, 2006; Stride et al., 2014), including marine and freshwater fishes growing either in natural environments or cultured in aquaculture farms. Mortality rates range from 4 to $100 \%$ in larvae and fingerlings, although the condition is usually benign in other age groups (Nowak and Clark, 1999; Crespo et al., 2001). Plehn (1920), who first described the disease as 'mucophilosis', presumed that the pathogen was a unicellular alga or fungus. Hoffman et al. (1969) recognised the bacterial nature of the aetiological agent and named the disease epitheliocys-

\footnotetext{
*Corresponding author; E-mail: sellyei.boglarka@agrar.mta.hu; Phone: 0036 (1) 467-4065
} 
tis. Based on ultrastructural studies Paperna et al. (1978) as well as Paperna and Sabnai (1980) supposed that the causative organism was a Chlamydia- or Rickettsia-like bacterium. During their light and electron microscopic studies, Molnár and Boros (1981) observed different intracellularly developing stages of the epitheliocystis organism in common carp fry. Accurate identification of the causative agent has been achieved only relatively recently, primarily with the help of molecular techniques (Everett et al., 1999; Draghi et al., 2004; Meijer et al., 2006). Further studies confirmed that the mysterious obligate intracellular Gram-negative bacterium belonged to the order Chlamydiales. Molecular classification of pathogens from epitheliocystis infections of different marine and freshwater fish species revealed 11 Chlamydia-like organisms. The taxonomic status of these agents has been disputed: Pawlikowska-Warych and Deptuła (2016) classified nine of them into six families, designated as Parachlamydiaceae, Rhabdochlamydiaceae, Candidatus Parilichlamydiaceae, Candidatus Clavichlamydiaceae, Candidatus Actinochlamydiaceae, Candidatus Piscichlamydiaceae, while Gupta et al. (2015) delineated three clades within the phylum Chlamydiae, each of them involved the families concerned, like Parachlamydiaceae (Para-, Proto-, Meso-, Meta-, Neochlamydia) and Candidatus families as Clavichlamydiaceae, Rhabdochlamydiaceae (Rhabdo-, Renichlamydia), Parilichlamydiaceae and Piscichlamydiaceae. New data suggest that some nonchlamydial, $\gamma$ - and $\beta$-proteobacteria could also be affiliated with the disease (Toenshoff et al., 2012; Contador et al., 2016). The majority of epitheliocystis cases have been reported in marine fish species, while relatively few infections (approx. 20 percent) are known in freshwater fishes (Stride et al., 2014). The affected freshwater fish species are the centrarchids bluegill (Lepomis macrochirus) and largemouth bass (Micropterus salmoides), the ictalurids brown bullhead (Ictalurus nebulosus) and channel catfish (Ictalurus punctatus), the clarid African catfish (Clarias gariepinus), the salmonid lake trout (Salvelinus namaycush), the acipenserid white sturgeon (Acipenser transmontanus), the latid barramundi (Lates calcarifer), the terapontid silver perch (Bidyanus bidyanus), the moronid white perch (Morone americanus) and striped bass (Morone saxatilis), the cichlid tilapias (Tilapia aurea $\times$ nilotica hybrid, T. nilotica, T. mossambica), and the caracid pacu (Piaractus mesopotamicus). Moreover, epitheliocystis has also been detected in the cyprinid common carp (Cyprinus carpio) and grass carp (Ctenopharyngodon idella) (Hoffman et al., 1969; Wolke et al., 1970; Zachary and Paperna, 1977; Paperna and Baudin-Laurencin, 1979; Paperna and Sabnai, 1980; Paperna et al., 1981; Zimmer et al., 1984; Bradley et al., 1988; Desser et al., 1988; Anderson and Prior 1992; Groff et al., 1996; Frances et al., 1997; Szakolczai et al., 1999; Goodwin et al., 2005; Meijer et al., 2006; Steinum et al., 2010; Steigen et al., 2013). Although epitheliocystis infection had been first recorded in the common carp (Plehn, 1920) and the disease was observed in cyprinid fishes from time to time in several regions of the world (Hungary - Molnár 
and Boros, 1981; Israel, Portugal - Paperna and Alves de Matos, 1984; Japan Miyazaki et al., 1986; Russia - Voronin and Chernysheva, 1997; South Korea Kim et al., 2005), the taxonomic status of the causative agents in these fishes has not been studied in sufficient detail. So far only a short Chlamydia-like sequence associated with epitheliocystis in the cyprinid grass carp (Ctenopharyngodon idella) has been deposited in GenBank (Kumar et al., 2013).

The objective of this study was to perform a phylogenetic comparison of the causative agents of epitheliocystis in common carp and gibel carp with those in other fish species, using sequence data published earlier.

\section{Materials and methods}

\section{Fishes}

In July and August of 2013-2015, during routine farm health monitoring and natural water surveillance altogether 240 common carp (Cyprinus carpio) and 27 gibel carp (Carassius auratus gibelio) specimens were studied for epitheliocystis infection. Common carp (2-4 months old and 4-10 cm in length) arrived from four fish farms in the eastern [farm 1 (sample EP2), 3 (sample EP5), and 4 (sample EP6)] and western [farm 2 (sample EP4)] parts of Hungary. From gibel carp (1-2 years old and 3-9 cm in length) 15 specimens were obtained from a fish farm and 12 specimens were collected from Lake Balaton and its tributaries. The fish were transported alive to the laboratory in plastic bags and kept in 40-litre aquaria.

\section{Sampling}

The fish were euthanised with 20 ppm clove oil (Javahery et al., 2012) added to the water and gill samples were collected. For further histological and molecular studies, specimens with a relatively high number of epitheliocysts were selected. Hemibranchia infected by various developmental stages of epitheliocystis were fixed in Bouin's solution, embedded in paraffin wax, cut to 4$5 \mu \mathrm{m}$ thick sections, and stained with haematoxylin and eosin. The cysts were carefully separated from tissue debris under a stereomicroscope at high magnification and in each case about 10 cysts were put in a vial into $70 \%$ ethanol and preserved for molecular studies.

\section{Molecular study}

Genomic DNA was extracted from homogenates of epitheliocysts (TissueLyser LT, Qiagen, Hilden, Germany) using a DNeasy Blood and Tissue Kit (Qiagen, Hilden, Germany) according to the manufacturer's instructions. As control, pieces of gill filaments of non-infected fishes were also homogenised and 
tested for chlamydial DNA. The presence of any Chlamydia-like organism was tested using the eight-primer combined universal PCR designed by Ossewaarde and Meijer (1999) with 'touchdown PCR' protocol. Briefly, fragments were amplified by PCR in an Applied Biosystems 2720 Thermal Cycler (Thermo Fisher Scientific, Carlsbad, CA, USA). The $45 \mu 1$ amplification reaction mixture contained $1 \times$ Dream Taq Buffer, $200 \mathrm{nM}$ dNTP-mix, $1 \mu \mathrm{M}$ of each primer, $1.25 \mathrm{U}$ Dream Taq (Thermo Fisher Scientific, Carlsbad, CA, USA), template DNA and water. The PCR program included $3 \mathrm{~min}$ of initial denaturation at $95^{\circ} \mathrm{C}$, and $7 \mathrm{~min}$ of the final elongation, then 35 cycles at $95^{\circ} \mathrm{C}$ for $30 \mathrm{~s}$, annealing for $30 \mathrm{~s}$, and at $72{ }^{\circ} \mathrm{C}$ for $30 \mathrm{~s}$. The annealing temperature of the reaction was decreased by $1{ }^{\circ} \mathrm{C}$ in every second cycle from $67^{\circ} \mathrm{C}$ to $57^{\circ} \mathrm{C}$, at which temperature $10 \mathrm{cy}$ cles were carried out. In the last 25 cycles the annealing temperature was $59^{\circ} \mathrm{C}$. The purified approximately 270-bp-long PCR fragments obtained using the Geneaid PCR purification Kit (Geneaid Biotech, New Taipei, Taiwan) were sequenced using an ABI Prism BigDyeTerminator Cycle Sequencing Kit v3.1 (Applied Biosystems, Perkin-Elmer) according to the producer's recommendations. Sequences were used for phylogenetic analysis; the alignment of 5 own and $4316 \mathrm{~S}$ rDNA sequences, including members of most families within the order Chlamydiales, especially data from cystic distortion of fish gills, was performed using MEGA6 software. The best-fit nucleotide substitution model for the dataset was GTR $+\mathrm{G}+\mathrm{I}$. Phylogenetic trees were built using a Maximum Composite Likelihood algorithm (with 1,000 bootstraps) and the NeighbourJoining method of tree topology reconstruction (Tamura et al., 2011).

In a further molecular study only the sequences of Piscichlamydia-related samples were extended successfully using specific PCR with Pisci211F and Pisci1363R primers (Toenshoff et al., 2012).

\section{Results}

Epitheliocystis infection was detected by light microscopic examination in common carp fingerlings from samples of four farms in Hungary. Twenty-six percent of the sources, altogether 62 common carp specimens and only a single gibel carp from a natural water source of the Zala river flowing into Lake Balaton were found infected. The pathological examinations detected epitheliocysts in the epithelium between the secondary lamellae of the gills (Fig. 1) as well as in the non-lamellar portions, at the dorsal and ventral edges and tips of the gill filaments (Fig. 2). Under the light microscope, at the first stage of infection, a clump of chlamydiae arranged in honeycomb structure was observed as a membrane-bound small inclusion body in the host cells. The inclusion increased in size due to multiplication of the infectious agent and was positioned centrally. At the end of the developmental process, the expanded inclusion occupied the bulk 
of the cytoplasmic compartment, enlarging the epithelial cell and pushing the nucleus into a corner (Fig. 3). Finally, the matured elementary bodies broke through the membrane, dispersed in the cytoplasm of the host cell and showed Brownian motion.

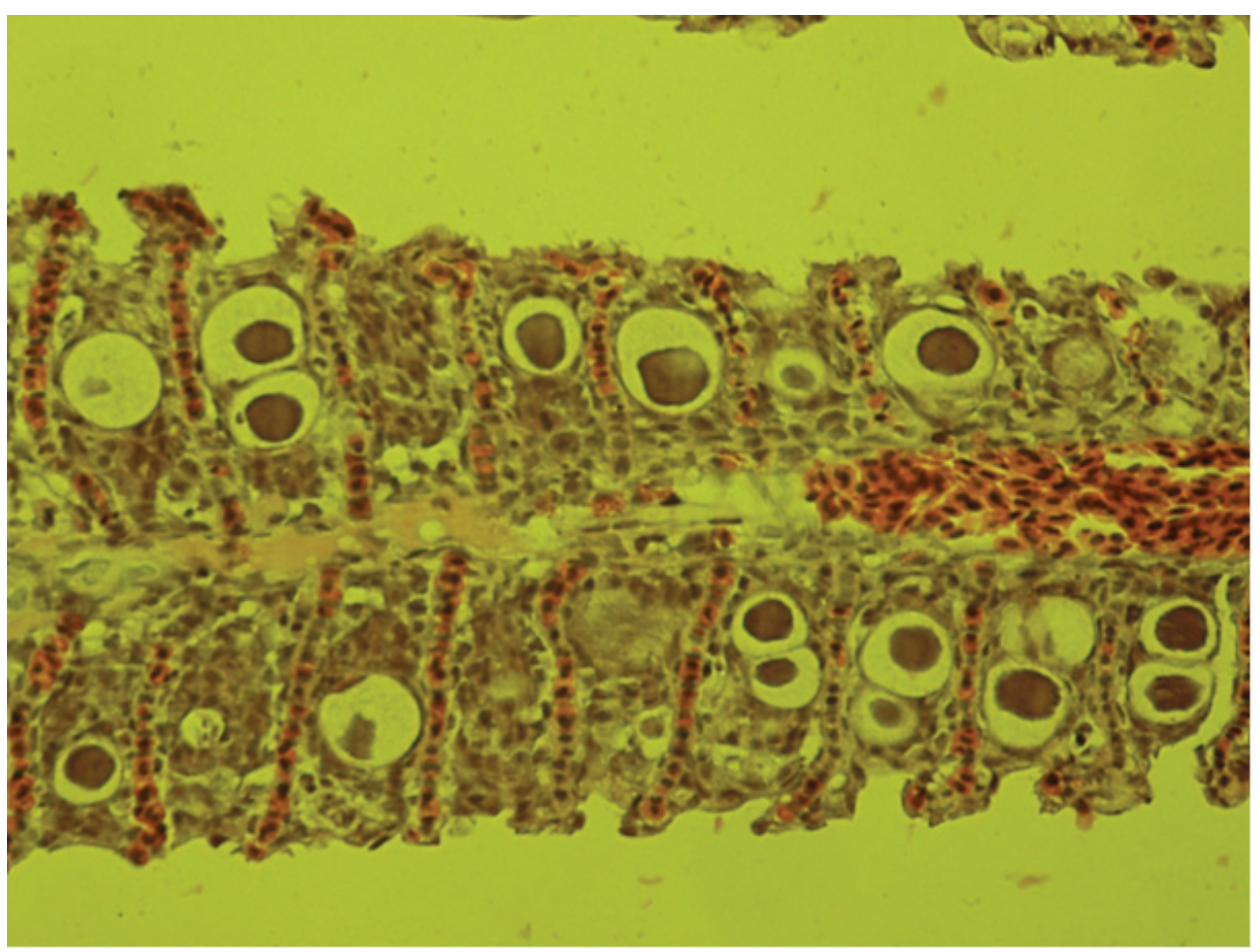

Fig. 1. Heavy epitheliocystis infection in the gill filament of a common carp fingerling. Cysts are located in the multilayered epithelium between the neighbouring gill lamellae. Inside the enlarged cells dark-staining bacteria accumulated in the centre of the degenerated mucous material of the host cell. Haematoxylin and eosin (HE) staining, $\times 500$

In histological sections stained by haematoxylin and eosin the early-stage vacuoles stained dark, while in a more developed stage of infection the enlarged, centrally located inclusions stained pale.

Although in two out of the five cases severe epitheliocystis infections were observed, the fish did not show apparent clinical signs.

The molecular study did not provide congruent results. DNA samples from cultured common carp (EP5 and EP6) from farms 3 and 4, respectively, and wild gibel carp (EP) from the Zala River showed sequence similarity to Piscichlamydia spp. detected in grass carp (Kumar et al., 2013) and Atlantic salmon (Draghi et al., 2004), while further two sequences from common carp were related to Protochlamydia and Neochlamydia spp. The EP5 and EP6 sequences 
showed $97.4 \%$ similarity to each other and $94.7 \%$ and $93 \%$ similarity, respectively, to the gibel carp sample. They differed from Candidatus Piscichlamydia cyprinis (JX470313) in 9.2\%, 7.5\% and 3.1\%, and from Candidatus Piscichlamydia salmonis (AY462244) in 11.5\%, 8.3\% and 5.3\%, respectively. Although longer fragments $(>1200 \mathrm{bp}$ ) from these samples were amplified and analysed successfully, a refreshed phylogenetic tree was not built, since the results did not shift their taxonomic status and a sufficiently long sequence of the putative closest-related sample from grass carp (Candidatus Piscichlamydia sp. E4, Kumar et al., 2013) is not available in the GenBank.

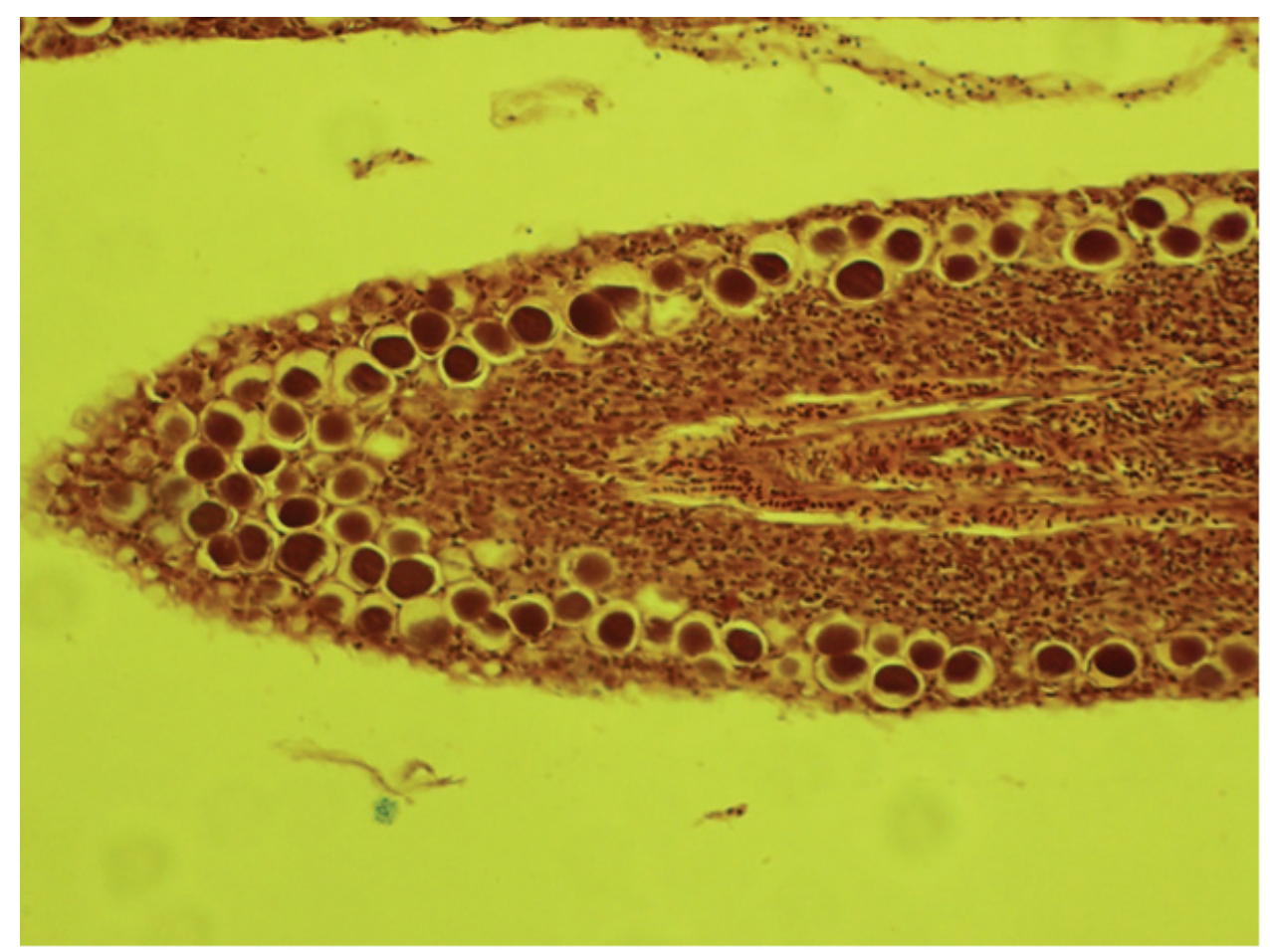

Fig. 2. Intensive epitheliocystis infection in the multilayered epithelium of the tip of a gill filament. HE staining, $\times 500$

The sequence of the EP2 common carp sample from fish farm 1 was related to the endosymbiont of Acanthamoeba sp. (AF098330) and Neochlamydia hartmannellae (AF177275) with $85.1 \%$ and $85.8 \%$ similarity, respectively. The sequence of the EP4 common carp sample from fish farm 2 showed close similarity to Protochlamydia naegleriophila from different sources (DQ632609, FJ976103, EU384664, and FJ976101). The sample differed from them in 12.6\%, $12.6 \%, 12 \%$ and $15.4 \%$, respectively (Fig. 4 ). In the control tissue samples not 
presenting visible chlamydial infection by light microscopy no sequences resembling known epitheliocystis agents were detected.

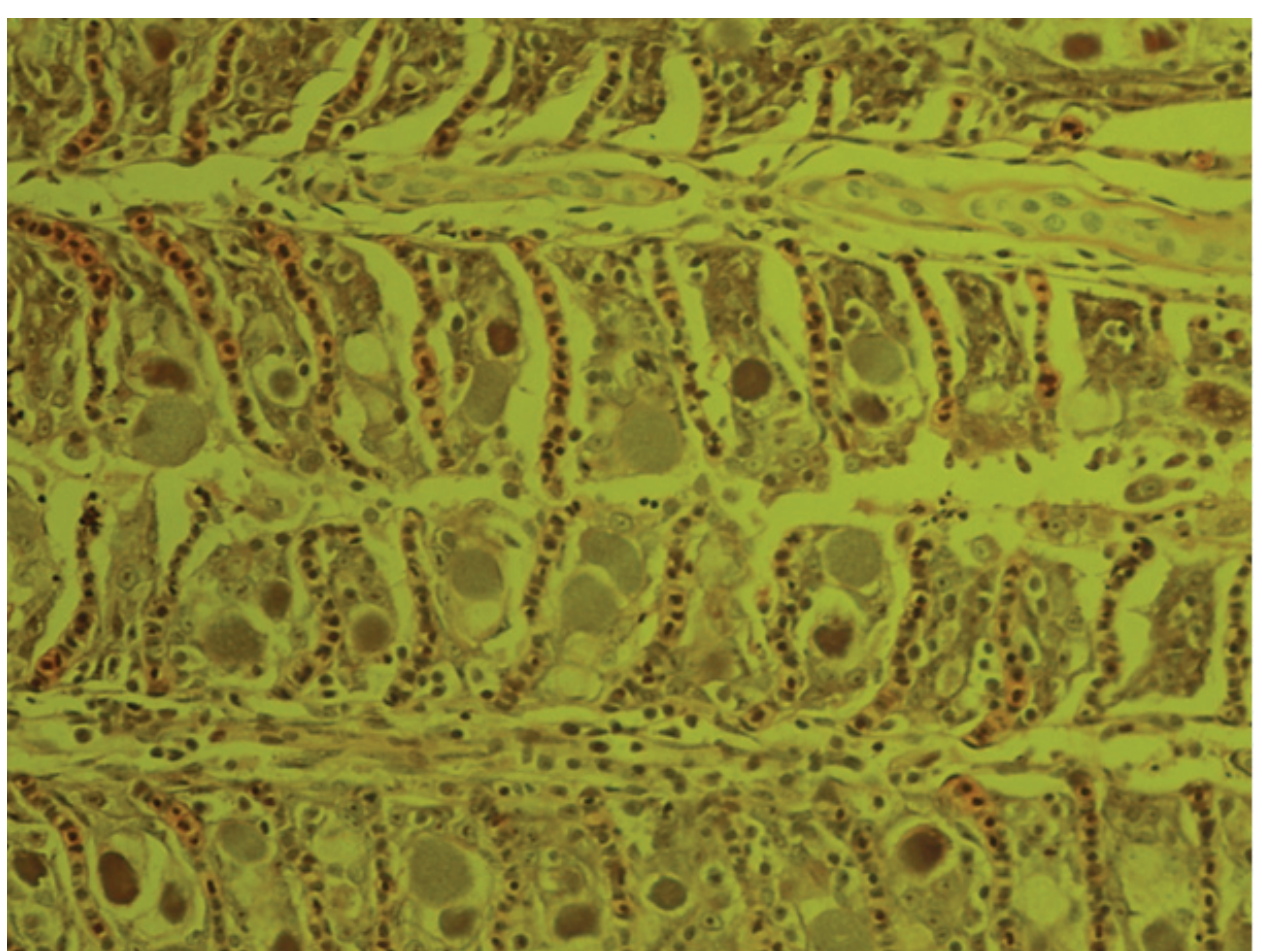

Fig. 3. Advanced epitheliocystis infection in the gills of a common carp fingerling. Some of the infected cells have compact, dark-staining, centrally located bacterial inclusions; in some pale-staining cells (arrows) bacteria have been dissolved in the mucous material of the degenerated cells. HE staining, $\times 500$

\section{Discussion}

Epitheliocystis causes significant economic losses to aquaculture all over the world (Nowak and Clark, 1999; Crespo et al., 2001). This infectious gill disease, histologically characterised by cysts in the branchial epithelia of the hosts, has been investigated mainly in marine fish species, although freshwater fishes are also affected (Nowak and LaPatra, 2006). Recent studies have revealed that several, primarily Chlamydia-like pathogens may contribute to the pathological changes developing in the gills (Stride et al., 2014).

Our observations on fingerlings of cultured common carp and wild gibel carp indicated the presence of different Chlamydia-like bacteria (Proto-, Neo-, and Piscichlamydia) as causative agents in epithelial infections of cyprinids. Epi- 

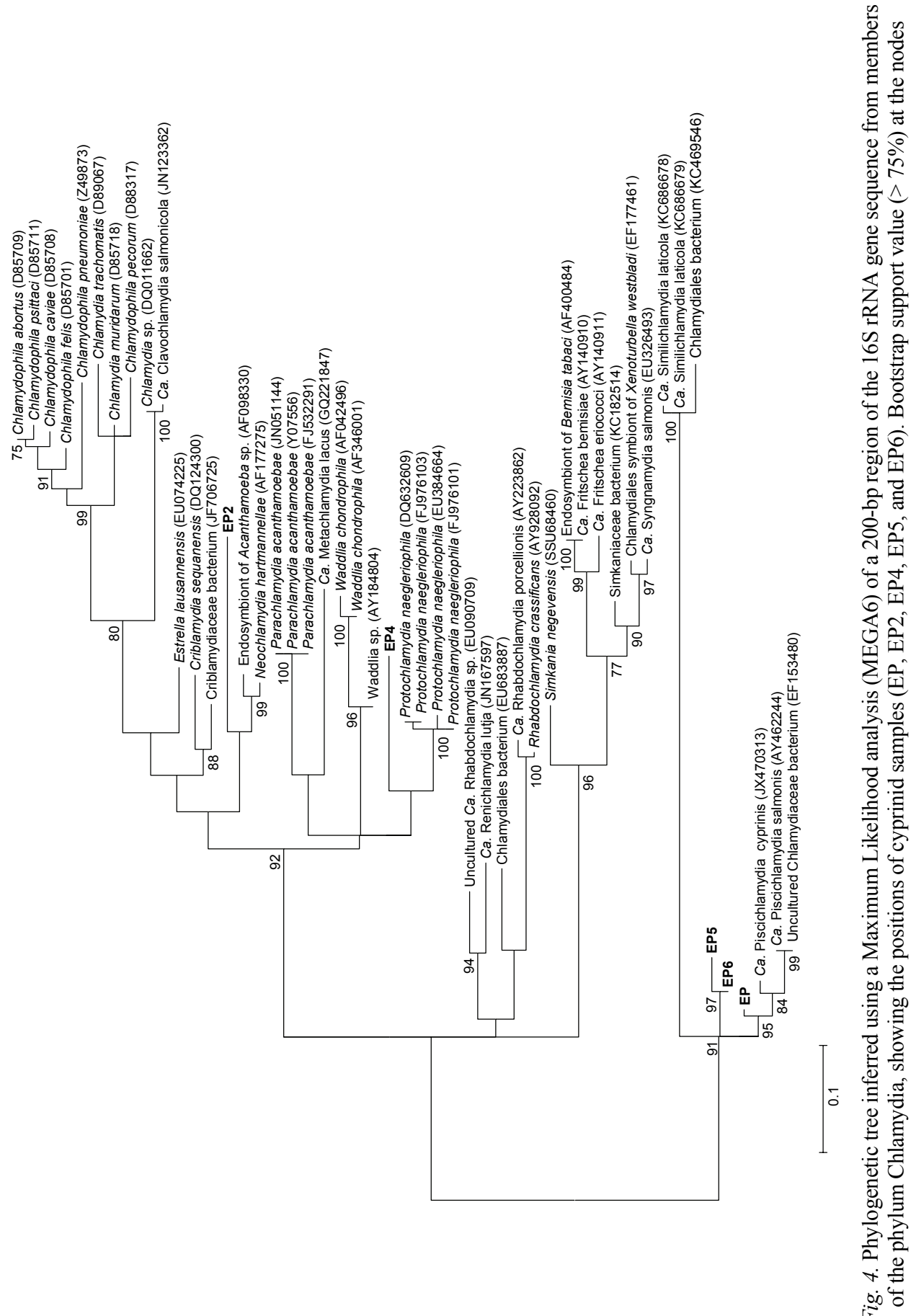

禹定 
theliocystis induced by various, distantly related organisms (Candidatus Piscichlamydia salmonis, Candidatus Clavichlamydia salmonicola and Candidatus Branchiomonas cysticola) has already been detected in Atlantic salmon as well (Nylund et al., 2015). Our results demonstrate that within a given host species diverse causative agents may be in the background of epitheliocystis infections, even if the hosts are in identical or very similar environments.

The variability mentioned above may be associated with the manifestation of the disease. Epitheliocystis occurs as a benign or severe proliferative disease, according to the inflammatory host response. In benign infections apparently only a slight host response could be detected, even in the presence of large numbers of cysts surrounded by a thin epithelial envelope layer. While the intense, proliferative host response induces hyperplasia in the branchial epithelium, the cysts forming concentric layers can cause respiratory insufficiency and mortality by obstructing the capillary network of the gill filament (Arkush and Bartholomew, 2011).

In the cases studied by us mostly benign infections were observed, but proliferative changes were also recorded. These latter changes were restricted to the multi-layered epithelium and never affected the epithelium of the respiratory lamellae.

In our specimens three different putative epitheliocystis agents, related to Neochlamydia, Protochlamydia and Piscichlamydia, were detected by sequence analysis of short regions of the $16 \mathrm{~S}$ rRNA gene. Piscichlamydia is a typical pathogenic agent of epitheliocystis, which was identified first (Draghi et al., 2004) in gill cysts of Atlantic salmon (Salmo salar). The proliferative changes were associated with heavy mortality and reduced growth of survivors on salmonid farms in Ireland and Norway. Neochlamydia hartmanellae and Protochlamydia naegleriophia (Horn et al., 2000; Michel et al., 2000), the initial members of their families, were first discovered as parasites of free-living amoebae (Hartmannella vermiformis, Naegleria lovaniensis). These bacteria could grow and survive in amoeboid hosts, which means that they had adapted to hidden intracellular life without killing their host. Occasionally they could be detected in both human and animal diseases (von Bomhard et al., 2003; Baud et al., 2008; Casson et al., 2008). Our observations suggest that the role of amoebae as the environmental reservoir of some epitheliocystis agents should be reconsidered.

\section{Acknowledgement}

This study was supported by the GINOP-2.3.2-15-2016-00004 project and the K 100132 grant from the Hungarian Scientific Research Fund (OTKA). 


\section{References}

Anderson, I. and Prior, H. C. (1992): Subclinical epitheliocystis in barramundi, Lates calcarifer, reared in sea cages. Austral. Vet. J. 69, 226-227.

Arkush, K. D. and Bartholomew, J. L. (2011): Piscirickettsia, Francisella and Epitheliocystis. In: Woo, K. and Bruno, D. W. (eds) Fish Diseases and Disorders. Volume 3: Viral, Bacterial and Fungal Infections. Second edition. CAB International, Wallingford, UK. pp. 302-337.

Baud, D., Regan, L. and Greub, G. (2008): Emerging role of Chlamydia and Chlamydia-like organisms in adverse pregnancy outcomes. Curr. Opin. Infect. Dis. 21, 70-76.

Bradley, T. M., Newcomer, C. E. and Maxwell, K. O. (1988): Epitheliocystis associated with massive mortalities of cultured lake trout Salvelinus namaycush. Dis. Aquat. Org. 4, 9-17.

Casson, N., Michel, R., Müller, K. D., Aubert, J. D. and Greub, G. (2008): Protochlamydia naegleriophila as etiologic agent of pneumonia. Emerg. Infect. Dis. 14, 168-172.

Contador, E., Methner, P., Ryerse, I., Huber, P., Lillie, B. N., Frasca, S. and Lumsden, J. S. (2016): Epitheliocystis in lake trout Salvelinus namaycush (Walbaum) is associated with a $\beta$ proteobacteria. J. Fish Dis. 39, 353-366.

Crespo, S., Zarza, C. and Padrós, F. (2001): Epitheliocystis hyperinfection in sea bass, Dicentrarchus labrax (L.): light and electron microscope observations. J. Fish Dis. 24, 557-560.

Desser, S., Paterson, W. and Steinhagen, D. (1988): Ultrastructural observations on the causative agent of epitheliocystis in the brown bullhead, Ictalurus nebulosus Lesueur, from Ontario and a comparison with the chlamydiae of higher vertebrates. J. Fish Dis. 11, 453-460.

Draghi, A. 2nd, Popov, V. L., Kahl, M. M., Stanton, J. B., Brown, C. C., Tsongalis, G. J., West, A. B. and Frasca, S. Jr. (2004): Characterization of 'Candidatus Piscichlamydia salmonis' (Order Chlamydiales), a chlamydia-like bacterium associated with epitheliocystis in farmed Atlantic salmon (Salmo salar). J. Clin. Microbiol. 42, 5286-5297.

Everett, K. D. E., Bush, R. M. and Anderson, A. A. (1999): Emended description of the order Chlamydiales, proposal of Parachlamydiceae fam. nov. and Simkaniaceae fam. nov., each containing one monotypic genus, revised taxonomy of the family Chlamydiaceae, including a new genus and five new species, and standards for the identification of organisms. Int. J. Syst. Evol. Microbiol. 49, 415-440.

Frances, J., Tennent, R. and Nowak, B. F. (1997): Epitheliocystis in silver perch, Bidyanus bidyanus (Mitchell). J. Fish Dis. 20, 453-457.

Goodwin, A. E., Park, E. and Nowak, B. F. (2005): Short communication: Successful treatment of largemouth bass, Micropterus salmoides (L.), with epitheliocystis hyperinfection. J. Fish Dis. 28, 623-625.

Groff, J. M., LaPatra, S. E., Munn, R. J., Anderson, M. L. and Osburn, B. I. (1996): Epitheliocystis infection in cultured white sturgeon, Acipenser transmontanus: antigenic and ultrastructural similarities of the causative agent to the chlamydiae. J. Vet. Diagn. Invest. 8, 172-180.

Gupta, R. S., Naushad, S., Chokshi, C., Griffiths, E. and Adeolu, M. (2015): A phylogenomic and molecular markers based analysis of the phylum Chlamydiae: proposal to divide the class Chlamydiia into two orders, Chlamydiales and Parachlamydiales ord. nov., and emended description of the class Chlamydiia. Antonie van Leeuwenhoek 108, 765-781.

Hoffman, G. L., Dunbar, C. E., Wolf, K. and Zwillenberg, L. O. (1969): Epitheliocystis, a new infectious disease of the bluegill (Lepomis macrochirus). Antonie van Leeuwenhoek. J. Microbiol. Ser. 35, 146-158.

Horn, M., Wagner, M., Müller, K-D., Schmid, E. N., Fritsche, T. R., Schleifer, K. H. and Michel, R. (2000): Neochlamydia hartmannellae gen. nov., sp. nov. (Parachlamydiaceae), an endoparasite of the amoeba Hartmannella vermiformis. Microbiology 146, 1231-1239.

Javahery, S., Nekoubin, H. and Moradlu, A. H. (2012): Effect of anaesthesia with clove oil in fish (review). Fish Physiol. Biochem. 38, 1545-1552. 
Kim, D. J., Park, J. H., Seok, S. H., Cho, S. A., Baek, M. W. and Lee, H. Y. (2005): Epitheliocystis in carp (Cyprinus carpio) in South Korea. J. Vet. Med. Sci. 67, 119-120.

Kumar, G., Mayrhofer, R., Soliman, G. and El-Matbouli, M. (2013): Novel Chlamydiales associated with epitheliocystis in grass carp (Ctenopharyngodon idella). Vet. Rec. 172, 47-49.

Meijer, A., Roholl, P. J. M., Ossewaarde, J. M., Jones, B. and Nowak, B. F. (2006): Molecular evidence for association of Chlamydiales bacteria with epitheliocystis in leafy seadragon (Phycodurus eques), silver perch (Bidyanus bidyanus), and barramundi (Lates calcarifer). Appl. Environ. Microbiol. 72, 284-290.

Michel, R., Müller, K-D., Hauröder, B. and Zöller, L. (2000): A coccoid bacterial parasite of Naegleria sp. (Schizopyrenida:Vahlkampfiidae) inhibits cyst formation of its host but not transformation to the flagellate stage. Acta Protozool. 39, 199-207.

Miyazaki, T., Fujimaki, Y. and Hatai, K. (1986): A light and electron microscopic study on epitheliocystis disease in cultured fishes. Nippon Suisan Gakkaishi 52, 199-202.

Molnár, K. and Boros, G. (1981): A light and electron microscopic study of the agent of carp mucophilosis. J. Fish Dis. 4, 325-334.

Nowak, B. F. and Clark, A. (1999): Prevalence of epitheliocystis in Atlantic salmon, Salmo salar L., farmed in Tasmania, Australia. J. Fish Dis. 22, 73-78.

Nowak, B. F. and LaPatra, S. E. (2006): Epitheliocystis in fish. J. Fish Dis. 29, 573-588.

Nylund, S., Steigen, A., Karlsbakk, E., Plarre, H., Andersen, L., Karlsen, M., Watanabe, K. and Nylund, A. (2015): Characterization of 'Candidatus Syngnamydia salmonis' (Chlamydiales, Simkaniaceae), a bacterium associated with epitheliocystis in Atlantic salmon (Salmo salar L.). Arch. Microbiol. 197, 17-25.

Ossewaarde, J. M. and Meijer, A. (1999): Molecular evidence for the existence of additional members of the order Chlamydiales. Microbiology 145, 411-417.

Paperna, I. and Alves de Matos, A. P. (1984): The developmental cycle of epitheliocystis in carp, Cyprinus carpio L. J. Fish Dis 7, 137-147.

Paperna, I. and Baudin-Laurencin, F. (1979): Parasitic infections of sea bass, Dicentrarchus labrax, and gilt head sea bream, Sparus aurata, in mariculture facilities in France. Aquaculture 16, 173-175.

Paperna, I. and Sabnai, I. (1980): Epitheliocystis disease in fishes. In: Ahne, W. (ed.) Fish Diseases. Springer-Verlag, Heidelberg. pp. 228-234.

Paperna, I., Sabnai, I. and Castel, M. (1978): Ultrastructural study of epitheliocystis organisms from gill epithelium of the fish Sparus aurata (L.) and Liza ramada (Risso) and their relation to the host cell. J. Fish Dis. 1, 181-189.

Paperna, I., Sabnai, I. and Zachary, A. (1981): Ultrastructural studies in piscine epitheliocystis: Evidence for a pleomorphic developmental cycle. J. Fish Dis. 4, 459-472.

Pawlikowska-Warych, M. and Deptuła, W. (2016): Characteristics of chlamydia-like organisms pathogenic to fish. J. Appl. Genet. 57, 135-141.

Plehn, M. (1920): Praktikum der Fischkrankheiten. In: Demoll, R. and Maier, H. N. (eds) Handbuch der Binnenfischerei Mitteleuropas. Schweizerbartsche Verlagsbuchhandlung, Stuttgart. pp. 301-429.

Steigen, A., Nylund, A., Karlsbakk, E., Akoll, P., Fiksdal, I. U., Nylund, S., Odong, R., Plarre, H., Semyalo, R., Skår, C. and Watanabe, K. (2013): 'Cand. Actinochlamydia clariae' gen. nov., sp. nov., a unique intracellular bacterium causing epitheliocystis in catfish (Clarias gariepinus) in Uganda. PLoS ONE 8, e66840.

Steinum, T., Kvellestad, A., Colquhoun, D. J., Heum, M., Mohammad, S., Grøntvedt, R. N. and Falk, K. (2010): Microbial and pathological findings in farmed Atlantic salmon Salmo salar with proliferative gill inflammation. Dis. Aquat. Org. 91, 201-211.

Stride, M. C., Polkinghome, A. and Nowak, B. F. (2014): Chlamydial infections of fish: diverse pathogens and emerging causes of disease in aquaculture species. Vet. Microbiol. 170, 19-27.

Szakolczai, J., Vetési, F. and Pitz, R. (1999): Epitheliocystis disease in cultured pacu (Piaractus mesopotamicus) in Brazil. Acta Vet. Hung. 47, 311-318. 
Tamura, K., Peterson, D., Peterson, N., Stecher, G., Nei, M. and Kumar, S. (2011): MEGA5: molecular evolutionary genetics analysis using maximum likelihood, evolutionary distance and maximum parsimony methods. Mol. Biol. Evol. 28, 2731-2739.

Toenshoff, E. R., Kvellestad, A., Mitchell, S. O., Steinum, T., Falk, K., Colquhoun, D. J. and Horn, M. (2012): A novel betaproteobacterial agent of gill epitheliocystis in seawater farmed Atlantic salmon (Salmo salar). PLoS One 7, e32696.

von Bomhard, W., Polkinghorne, A., Lu, Z. H., Vaughan, L., Vögtlin, A., Zimmermann, D. R., Spiess, B. and Pospischil, A. (2003): Detection of novel chlamydiae in cats with ocular disease. Am. J. Vet. Res. 64, 1421-1428.

Voronin, V. N. and Chernysheva, N. B. (1997): Epitheliocystis infection in common carp Cyprinus carpio L.: histopathology and pathogenicity. Bull. Eur. Assoc. Fish Pathol. 17, 137-139.

Wolke, R. E., Wyand, D. S. and Khairallah, L. H. (1970): A light and electron microscopic study of epitheliocystis disease in the gills of Connecticut striped bass (Morone saxatilis) and white perch (Morone americanus). J. Comp. Pathol. 80, 559-563.

Zachary, A. and Paperna, I. (1977): Epitheliocystis disease in the striped bass Morone saxatilis from the Chesapeake Bay. Can. J. Microbiol. 23, 1404-1414.

Zimmer, M. A., Ewing, M. S. and Kocan, K. M. (1984): Epitheliocystis disease in the channel catfish, Ictalurus punctatus (Rafinesque). J. Fish Dis. 7, 407-410. 